\title{
A PROSPECTIVE SINGLE-BLINDED STUDY ON THE SAFETY AND EFFICACY OF ZINC SUPPLEMENTATION IN PULMONARY TUBERCULOSIS
}

\section{YESWANTH PRASANNA KUMAR B ${ }^{1}$, PRAVEEN ${ }^{2}$, RANADHEER CHOWDARY P², VIJEY AANANDHI ${ }^{3 *}$}

${ }^{1}$ Department of Pharmacy Practice, School of Pharmaceutical Sciences, Vels Institute of Science Technology and Advanced Studies, Chennai, India. ${ }^{2}$ Research Scholar, School of Pharmaceutical Sciences, Vels Institute of Science Technology and Advanced Studies, Chennai, India. ${ }^{3}$ Department of Pharmaceutical Chemistry and Analysis, School of Pharmaceutical Sciences, Vels Institute of Science Technology and Advanced Studies, Chennai, India. Email: hodpchemistry@velsuniv.ac.in

Received: 10 October 2018, Revised and Accepted: 11 December 2018

\section{ABSTRACT}

Aim and Objectives: The aim of the study was to study the serum zinc (Zn) levels, safety, and efficacy of Zn supplementation in pulmonary tuberculosis (PTB) patients.

Methods: A randomized single-blinded study of two groups: Group A received conventional TB therapy while Group B received conventional TB therapy along with $15 \mathrm{mg}$ of Zn tablet. 40 patients were assigned in each group by randomized permuted blocks.

Results: After 8 weeks of treatment in Group A 27 patients and Group B 36 patients were found to be sputum negative with p=0.0421 and 0.0629 . After 24 weeks of treatment in Group A 37 patients and Group B 40 patients were found to be sputum negative with p=0.00976 and 0.00971 . By this, the given treatment was effective in the patients with PTB.

Conclusion: Zn supplementation improves the effect of TB medication treatment and results in earlier sputum smear conversion.

Keywords: Micronutrient, Pulmonary Tuberculosis, Zinc

(C) 2018 The Authors. Published by Innovare Academic Sciences Pvt Ltd. This is an open access article under the CC BY license (http://creativecommons. org/licenses/by/4. 0/) DOI: http://dx.doi.org/10.22159/ajpcr.2018.v11s2.31685

\section{INTRODUCTION}

Tuberculosis (TB) is the leading cause of death and it caused by Mycobacterium TB. TB has been known for 5000 years, and the morbidity and mortality rate is high and yet goes on. Despite the fact that World Health Organization in its attempt to control TB declared as Global emergency in 1993, TB is still highly mortal. It is the second leading cause of adult death. In India, approximately 4.81 thousand people are suffering from TB [1]. In 2016, there were $>10$ million instances of active TB, which resulted in 1.3 million deaths. $>90 \%$ of death taking place in growing nations.

Weight loss is the major fundamental sign and general symptoms include fever, shivering, loss of appetite, and tiredness. The treatment of active $\mathrm{Tb}$ was available from half a century.

The observation of micronutrient deficiencies in adults with TB led to intervention studies and to explore whether replacing would improve patients' recovery [2]. Zinc (Zn) deficiency affects host defense by detaining phagocytosis and reducing the number of $\mathrm{T}$ cells. $\mathrm{Zn}$ has a very prominent part in cell-mediated immune function and likewise serve as anti-inflammatory and antioxidant in TB [3-6]

Several studies have shown that the serum levels of $\mathrm{Zn}$ decrease significantly during active TB and increase the following recovery after the institution of anti-TB therapy and improvement of the nutritional status [7-9].

\section{Subject selection and methodology}

The above study was performed in the department of pulmonology in one public hospital in Chennai, Tamil Nadu, from August 2017 to April 2018. The studies were picked out along the basis of the following criteria: Age above 18 years, three sputum specimens which are positive for acid-fast bacilli by direct microscopy and culture, and consistent by clinical and radiologic signs with pulmonary TB (PTB), and no state of past anti-TB treatment. In exclusion criteria were patients who are diagnosed with extra-PTB and with multidrug-resistant TB and extensively drug-resistant TB; pregnant and nursing women; and diagnosed with IBD and lung carcinoma. The work was sanctioned by the Ethics Committee Vels Institute of Science Technology and Advanced Studies-SPS/IEC/ II/2017/03.

\section{METHODS}

The study was designed as prospective observational; singleblinded. Patients diagnosed at the study center as PTB positive were randomized. Two allocation sequences, using blocks of four, were created using computer-generated random numbers. Study numbers were then assigned consecutively to the generated sequence numbers. The two groups are divided; Group A receives normal directly observed treatment short course (DOTS) regimen whereas Group B receives DOTS regimen with the addition of $\mathrm{Zn} 15 \mathrm{mg}$ once daily. The sample size was calculated for a random sampling of 100 persons with the confidence interval of $95 \%$ the sample size was found to be 80 with a $5.75 \%$ margin of error.

\section{Outcome measures}

The effect was to estimate the serum $\mathrm{Zn}$ levels I well established PTB patients and to contemplate the efficacy and safety of $\mathrm{Zn}$ supplementation in PTB patients.

\section{Statistical analysis}

Data were analyzed in SPSS for windows version 10.0. Efficacy will be analyzed on the basis of Chi-square test while safety will be assessed using student t-test with $95 \%$ level of significance and "p" $<0.05$ is considered significant. 


\section{RESULTS}

Fig. 1 shows the age distribution among the different age groups. The number of patients in age group of 18-35 was 21 (26.25\%), 36-59 was $19(23.75 \%), 60-85$ was $26(32.5 \%)$, and $>85$ was $14(17.5 \%)$.

Fig. 2 shows the gender distribution among the patients. 56 (70\%) were male and $24(30 \%)$ were female.

Table 1 shows the economic status of the patients. Patients with poor economic status were 27 (33.75\%), low- and middle-income were 38 (47.5\%), and middle-income were 15 (18.75\%).

Fig. 3 shows the educational qualification in which $<10^{\text {th }}$ Grade was 41 (51.25\%), high school 22 (27.5\%), diploma 10 (12.5\%), UG 6 (7.5\%), and PG 1 (1.25\%).

Table 2 discuss about the area location of the patients. In rural $16(20 \%)$ and Urban $64(80 \%)$ were present.

Table 3 describes about the marital status of the patients in the study. In the total patients, 51 (63.75\%) were married and 29 (36.25\%) were single.

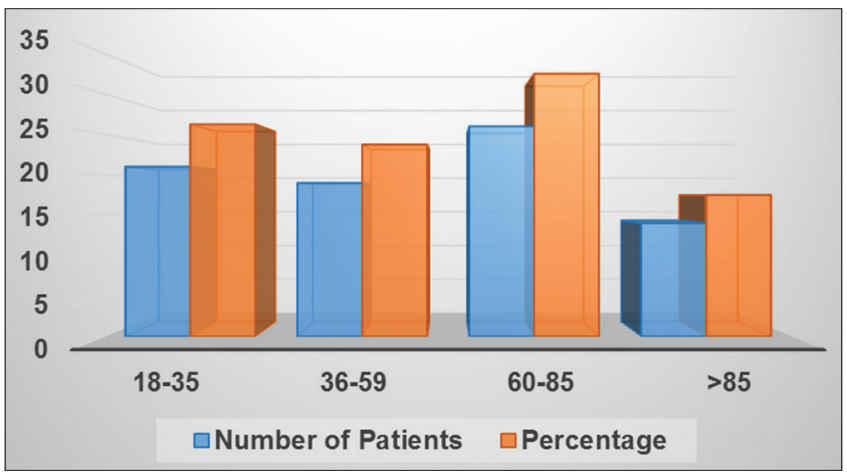

Fig. 1: Age distribution

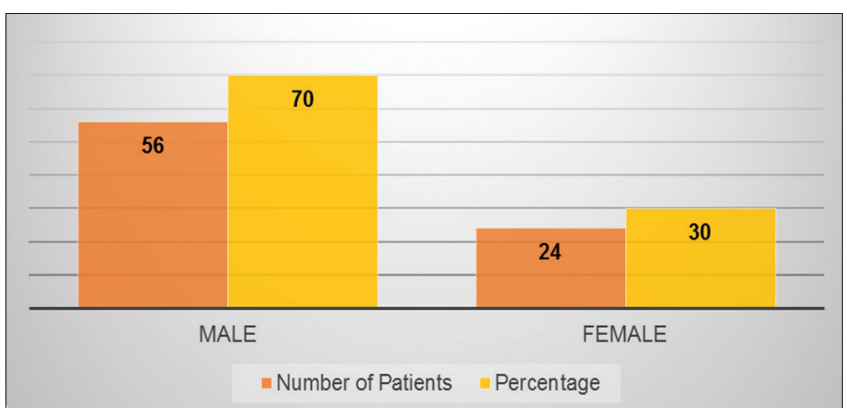

Fig. 2: Gender distribution

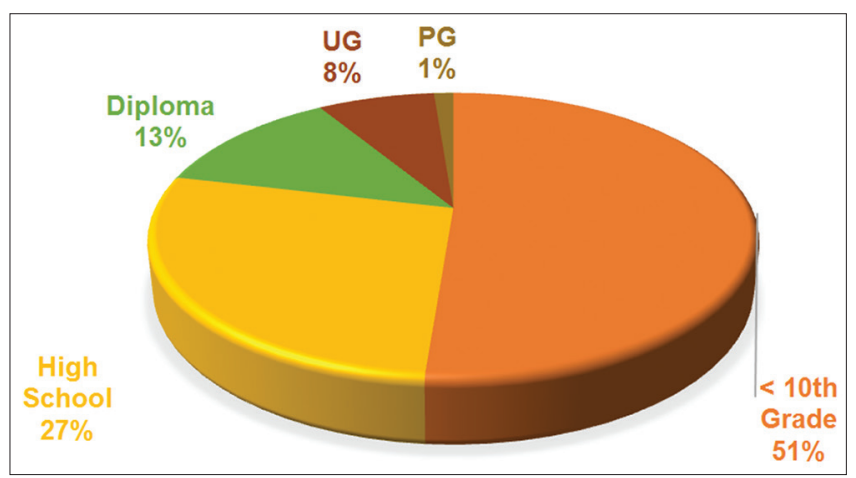

Fig. 3: Educational qualification
Fig. 4 shows the social habits such as alcohol, smokers, and both habits among the patients.

Table 4 shows the comorbidity conditions among the patients. HTN 12 , DM 29, cardiovascular disease (CVD) 6, BA 12, Lymphadenitis 6, HIV 2, and none with 40 among the patients.

Fig. 5 shows the comorbidity conditions among the patients. HTN 12 , DM 29, CVD 06, BA 12, Lymphadenitis 6, HIV 2, and none with 40 among the patients.

Fig. 6 shows about the cavitary lesions of the patients 23.75\% (19) patients were found with cavitary lesions and 61 (76.25\%) patients were found with non-cavitary lesions.

Table 5 shows the baseline characteristics grouping among the patients. Number of zones affected on lungs among the Group A patients is $2.7 \pm 0.6$ and in Group B it is $2.9 \pm 0.9$. Serum $\mathrm{Zn}$ levels in Group A were $0.29 \pm 0.26$ whereas in Group B the serum $\mathrm{Zn}$ levels were $0.32 \pm 0.78$.

Fig. 7 shows the baseline characteristics grouping among the patients. Number of zones affected on lungs among the Group A patients is $2.7 \pm 0.6$, and in Group B it is $2.9 \pm 0.9$. Serum $\mathrm{Zn}$ levels in Group A were $0.29 \pm 0.26$ whereas in Group B the serum Zn levels were $0.32 \pm 0.78$.

Table 6 shows the efficacy statement in the patients after 2 months. In Group A sputum negative was seen in 27 and Group B sputum negative is seen in 36 .

Fig. 8 shows the efficacy statement in the patients after 2 months. In Group A sputum negative was seen in 27 and Group B Sputum negative is seen in 36 .

Table 7 shows the efficacy statement in the patients after 6 months. In Group A sputum negative was seen in 37 and Group B sputum negative was seen in 40 .

Table 1: Economic status

\begin{tabular}{lll}
\hline S. No & Economic status & Number of patients (\%) \\
\hline 1. & Poor & $27(33.75)$ \\
2. & Low middle Income & $38(47.5)$ \\
3. & Middle Income & $15(18.75)$ \\
4. & High Income & -- \\
\hline
\end{tabular}

Table 2: Location

\begin{tabular}{lll}
\hline S. No. & Location & Number of patients (\%) \\
\hline 1. & Rural & $16(20)$ \\
2. & Urban & $64(80)$ \\
\hline
\end{tabular}

Table 3: Marital status

\begin{tabular}{lll}
\hline S. No. & Marital status & Number of patients (\%) \\
\hline 1. & Married & $51(63.75)$ \\
2. & Single & $29(36.25)$ \\
\hline
\end{tabular}

Table 4: Comorbidities

\begin{tabular}{lll}
\hline S. No. & Comorbidity & Number of patients (\%) \\
\hline 1. & HTN & $12(15)$ \\
2. & DM & $29(32.5)$ \\
3. & CVD & $06(7.5)$ \\
4. & BA & $12(15)$ \\
5. & Lymphadenitis & $06(7.5)$ \\
6. & HIV & $02(2.5)$ \\
7. & None & $40(50)$ \\
\hline
\end{tabular}

CVD: Cardiovascular disease 
Table 5: Grouping - baseline characteristics

\begin{tabular}{|c|c|c|c|c|}
\hline S. No. & Parameter (\%) & Group A n (\%)=40 & Group B n (\%)=40 & 'p' value \\
\hline 1. & Age (mean \pm SEM) & $51.6 \pm 3.2$ & $52.1 \pm 6.1$ & 0.0932 \\
\hline 2. & Male $\mathrm{n}$ & 23 & 33 & 0.0762 \\
\hline 3. & Alcoholic n & 10 & 08 & 0.0862 \\
\hline 4. & Smokers n & 19 & 13 & 0.0652 \\
\hline 6. & HIV n & 01 & 01 & 0.0982 \\
\hline 7. & Cavitary lesions n & 11 & 08 & 0.0542 \\
\hline 8. & HTN n & 07 & 05 & 0.0982 \\
\hline 10. & BMI (mean \pm SEM $)$ & $19.1 \pm 3.2$ & $18.9 \pm 2.9$ & 0.0527 \\
\hline 11 & Serum $\mathrm{Zn}$ level $(\mathrm{mcg} / \mathrm{ml})$ & $0.29 \pm 0.26$ & $0.32 \pm 0.78$ & 0.05217 \\
\hline 12. & Number of patients of zones affected on lungs & $2.7 \pm 0.6$ & $2.9 \pm 0.9$ & 0.07421 \\
\hline 13. & $\mathrm{ESR}(\mathrm{mm} / \mathrm{hr})$ & $39.6 \pm 4.8$ & $32.9 \pm 6.2$ & 0.05121 \\
\hline 14. & $\mathrm{CRP}$ & $5.1 \pm 2.7$ & $4.9 \pm 2.6$ & 0.07621 \\
\hline
\end{tabular}

ESR: Erythrocyte sedimentation rate, CRP: C-reactive protein, Zn: Zinc

Table 6: Efficacy assessment

\begin{tabular}{llll}
\hline After 2 months & & & \\
\hline Groups & Group A & Group B & p value \\
\hline Sputum negative & 27 & 36 & $0.0421^{*}$ \\
Sputum positive & 13 & 04 & $0.0629^{*}$ \\
\hline
\end{tabular}

Table 7: Efficacy assesment

\begin{tabular}{llll}
\hline After $\mathbf{6}$ months & & & \\
\hline Groups & Group A & Group B & p value \\
\hline Sputum negative & 37 & 40 & 0.00976 \\
Sputum positive & 03 & 00 & 0.00971 \\
\hline
\end{tabular}

Table 8: Serum Zn levels

\begin{tabular}{llll}
\hline S. No. & 2 months & 6 months & p value \\
\hline A & $0.32 \pm 0.16$ & $0.39 \pm 0.26$ & 0.0976 \\
B & $0.86 \pm 0.17$ & $1.21 \pm 0.14$ & $0.0217^{* *}$ \\
p value & $0.0216^{*}$ & $0.0010^{* *}$ & \\
\hline Zn: Zinc & & &
\end{tabular}

Table 9: ADR

\begin{tabular}{lllll}
\hline S. No. & ADR & Group A & Group B & p value \\
\hline 1. & Abnormal LFT & 06 & 07 & 0.0976 \\
2. & Nausea & 03 & 02 & 0.0978 \\
3. & Vomiting & 06 & 08 & 0.0827 \\
4. & Constipation & 02 & 06 & 0.0527 \\
5. & GI disturbances & 04 & 01 & 0.0626 \\
\hline
\end{tabular}

ADR: Adverse drug reactions, LFT: Liver function tests

Fig. 9 shows the efficacy statement in the patients after 6 months. In Group A sputum negative was seen in 37 and Group B sputum negative was seen in 40

Table 8 shows the serum Zn levels in the patients of two Groups A and B. In Group A after 2 months serum $\mathrm{Zn}$ levels were $0.32 \pm 0.16$. In Group B it was $0.86 \pm 0.17$.

After 6 months, the serum Zn levels in Group A $0.86 \pm 0.17$ and Group B $1.21 \pm 0.14$

Fig. 10 shows the serum Zn levels in the patients of two Groups A and B. In Group A, after 2 months serum Zn levels were $0.32 \pm 0.16$. In Group $\mathrm{B}$, it was $0.86 \pm 0.17$.

After 6 months the serum Zn levels in Group A $0.86 \pm 0.17$ and Group B $1.21 \pm 0.14$.

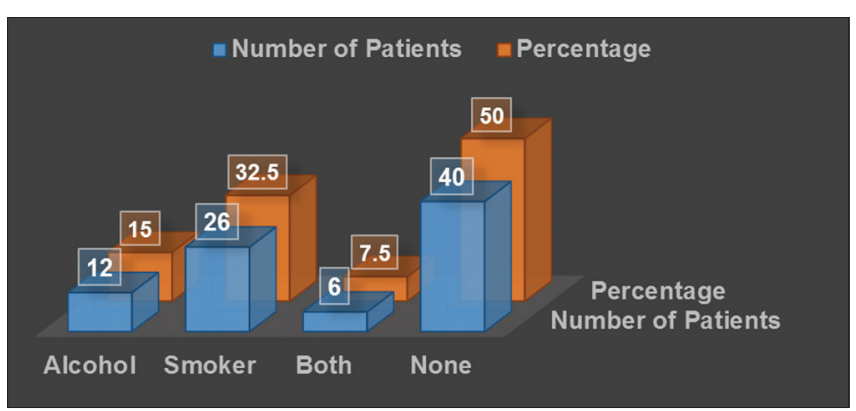

Fig. 4: Social habits

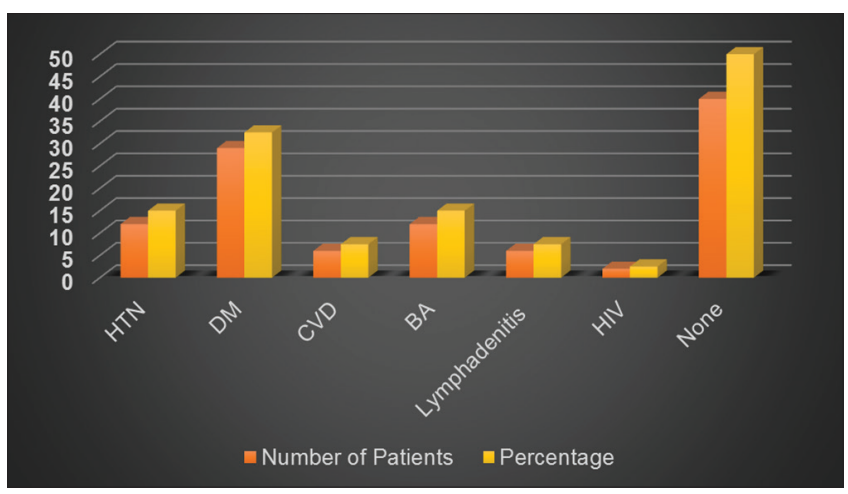

Fig. 5: Comorbidities

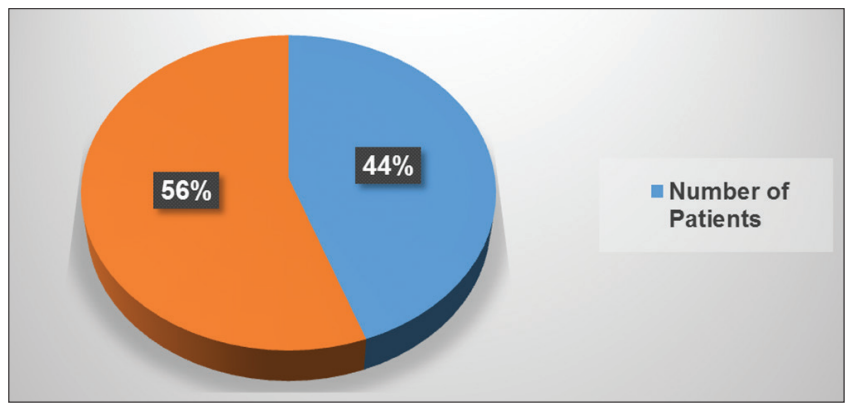

Fig. 6: Cavitary lesions

Table 9 shows that adverse drug reactions reported in the trial groups. There is no much difference between the two groups.WW

\section{DISCUSSION}

The above subject area was held out to assess the Zn levels in serum in patients diagnosed with PTB. In this, the male population is dominated 


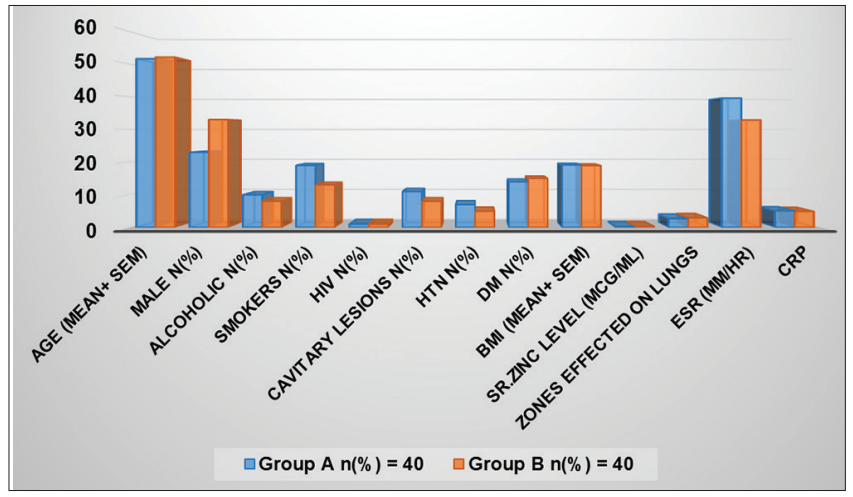

Fig. 7: Grouping - base line characteristics

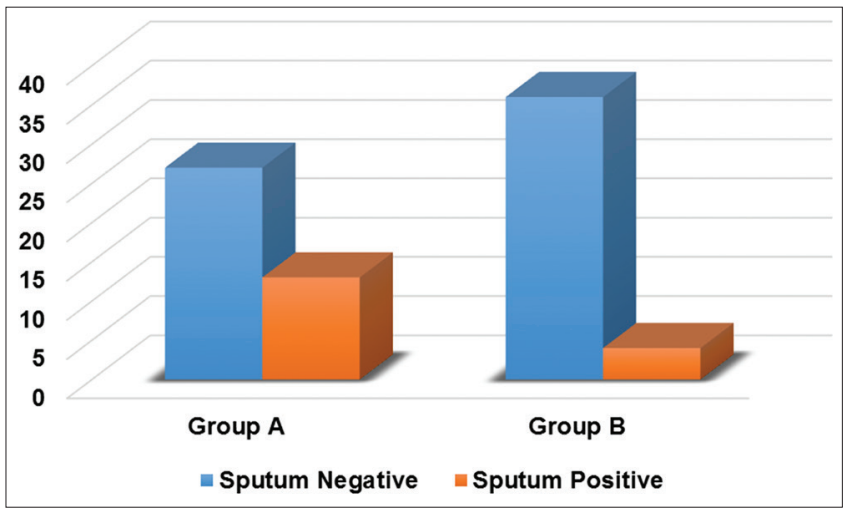

Fig. 8: Efficacy assessment (2 months)

among study topics which may be a genetic and community factor, a survey conducted in India said that $70 \%$ of the study subjects are males [10]. A written statement from a study in Indonesia also reported more amount of males in the study subjects [11]. In the study subjects, the mean age of male patients was $51.62 \pm 6.3$ years.

Zn levels in the serum were estimated in the study population, and it was observed that the patients with PTB had low Zn levels in serum. It may be due to the distribution of $\mathrm{Zn}$ from plasma to other tissues, reduction of the $\mathrm{Zn}$-carrier protein $\alpha$-macroglobulin in the hepatic production and to an increase in the secretion of melatonin that transports $\mathrm{Zn}$ to the liver.

It was reported that above $89 \%$ of patients in the present study had low $\mathrm{Zn}$ level in serum Lower than the characteristic value $(0.29 \mathrm{mcg} / \mathrm{ml})$ [12]. In this present work, the average $\mathrm{Zn}$ level in serum reported among study populations was $0.29 \pm 0.26 \mathrm{mcg} / \mathrm{ml}$ [13]. The standardized reports are entered in some other field. They too reported that the mean serum $\mathrm{Zn}$ level in the study population was $0.89 \pm 0.52 \mathrm{mg} / \mathrm{ml}$ and another study reported that the average $\mathrm{Zn}$ level among pulmonary TB patients was $9.7 \pm 1.8 \mathrm{mmol} / \mathrm{L}[10]$.

In our work, there is significant growth in $\mathrm{Zn}$ concentrations levels in serum occurred in the supplemented groups at 2 and 6 months of treatment. Information from the supplementation group showed significant growth in plasma $\mathrm{Zn}$ concentrations after 2 months, but significant growth is entered at the end of treatment in both supplemented and non-supplemented participants [14,6]. The outcome of symptomatic disease on $\mathrm{Zn}$ homeostasis should be taken. Higher amount of $\mathrm{Zn}$ is taken down in liver, than in serum [15]. The supplementation of $\mathrm{Zn}$ improved the strength of anti-TB drug at the end of the 6 months treatment. During the course of treatment, drug aims to kill the active tuberculin bacilli, and the subsequent treatment aims to kill resident tuberculin bacilli. The purpose of the DOTS regimen is to monitor treatment action and the drug concentration variation changes

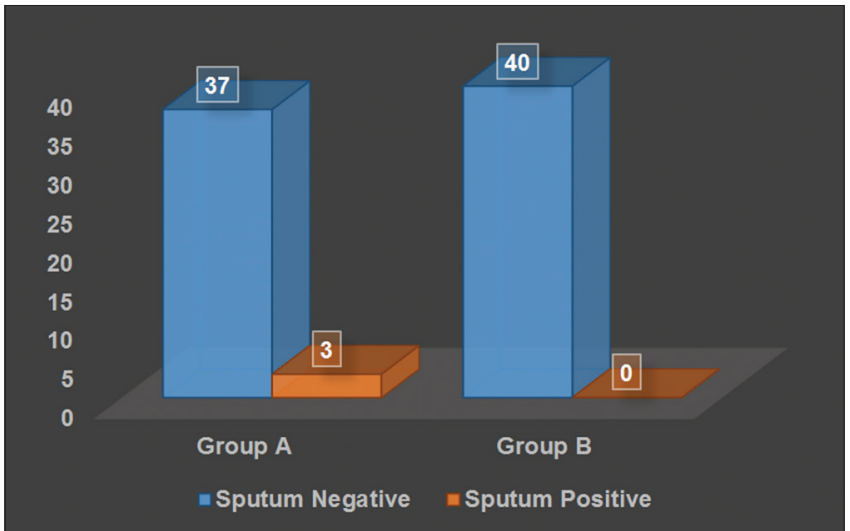

Fig. 9: Efficay assesment (6 months)

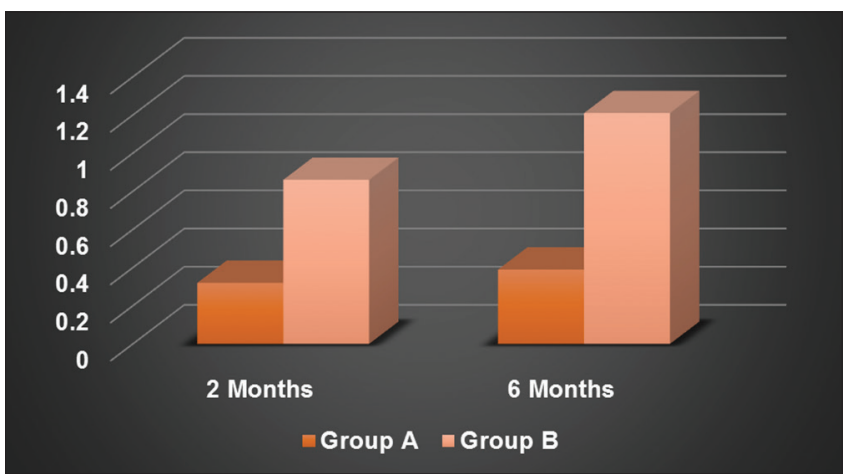

Fig. 10: Serum Zinc levels

which may be observed in sputum positivity. The result in the Zn group was recorded by the more no of patients with sputum negative for active bacilli and significantly average lower lesion area in the lungs.

Another survey recorded in India showed that TB treatment with four drugs in patients who are sputum-positive TB resulted in unacceptably high relapse rates in a period of 3 months [16,17]. $\mathrm{Zn}$ supplementation showed an effect on treatment outcome in first 2 months and improvement after 6 months. Basing the results our survey suggests that it would be useful to add micronutrients to the current TB treatment regimens. Sputum smear conversion was significantly faster in the Zn group than in the other group after 6 months of anti-TB treatment.

\section{CONCLUSION}

By above study and results, we conclude that micronutrient supplementation had effect on outcome in earlier sputum conversion at the end of 6 months therapy in participants with PTB. The survey also says that more patients presented with PTB case present with low Zn concentration in serum, which is a factor for estimation of Zn levels in serum and attains an instrument in the treating PTB patients. Zn tablet is suggested to be an important part for the regimen.

Laboratory estimation of the $\mathrm{Zn}$ levels could be employed to evaluate the strength of the ongoing anti-tuberculous therapy. Further clinical trials with longer study periods are needed to evaluate the efficacy of such interventions on treatment issues.

\section{REFERENCES}

1. World Health Organization. Implementing the WHO Stop TB Strategy:A Handbook for National TB Control Programmes. Geneva: World Health Organization; 2008. p. 179.

2. Fraker PJ, King LE. Reprogramming of the immune system during zinc deficiency. Ann Rev Nutr 2004;24:277-298 
3. Moynahan EJ. Zinc deficiency and cellular immunodeficiency in acrodermatitis enteropathicain man and zinc deficiency with thymichypoplasiain fresian calves: A possible genetic link. Lancet 1977;2:1057-9.

4. Koyanagi A, Kullo D, Gresley L, Shenkin A, Cuevas LE. Relationships between serum concentrations of C-reactive protein and micronutrients in patients with tuberculosis. Ann Trop Med Parasitol 2004;98:391-400.

5. Wiid T, Seaman T, Hoal EG, Benade AJ, Van Helden PD. Total antioxidant levels are low during active $\mathrm{TB}$ and rise with antituberculosis therapy. IUBMB Life 2004;56:101-6.

6. Karyadi E, West CE, Schultink W, Nelwan RH, Gross R, Amin Z, et al. A double-blind, placebo-controlled study of Vitamin A and zinc supplementation in persons with tuberculosis in Indonesia: Effects on clinical response and nutritional status. Am J Clin Nutr 2002;75:720-7.

7. Deveci F, Ilhan N. Plasma malondialdehyde and serum trace element concentrations in patients with active pulmonary tuberculosis. Biol Trace Elem Res 2003;95:29-38.

8. Lin X, Ding L, Wang Y, Yang Y. Determination of trace elements in serum of tuberculosis patients. Wei Sheng Yan Jiu 2000;29:395-6.

9. Milano A, Branzoni M, Canneva F, Profumo A, Riccardi G. The Mycobacterium tuberculosis Rv2358-furB operon is induced by zinc. Res Microbiol 2003;155:192-200.

10. Khanna BK, Kumar R, Mukerji PK, Chowdhury AR, Kamboh VP. Plasma copper and zinc levels in pulmonary tuberculosis. Ind J Tub
1982;29:179-84

11. Karyadi E, Schultink W, Nelwan RH, Gross R, Amin Z, Dolmans WM, et al. Poor micronutrient status of active pulmonary tuberculosis patients in Indonesia. J Nutr 2000;130:2953-8.

12. Ghulam H, Kadri SM, Manzoor A, Waseem Q, Aatif MS, Khan GQ, et al. Status of zinc in pulmonary tuberculosis. J Infect Dev Ctries 2009;3:365-8

13. Duzova H, Karagozler AA, Tekerekoglu MS, Emre MH. Serum zinc and copper levels in cases with Mycobacterium tuberculosis. Ege Tip Dergisi 2000;39:173-6.

14. Pakasi TA, Karyadi E, Wibowo Y, Simanjuntak Y, Suratih NM, Salean M, et al. Vitamin A deficiency and other factors associated with severe tuberculosis in Timor and Rote Islands, East Nusa Tenggara Province, Indonesia. Eur J Clin Nutr 2009;63:1130-5.

15. Brown KH. Effect of infections on plasma zinc concentration and implications for zinc status assessment in low-income countries. Am J Clin Nutr 1998;68 Supp 1:425S-9.

16. Tuberculosis Research Centre, Madras, andW National Tuberculosis Institute, Bangalore. A controlled clinical trial of 3- and 5-month regimens in the treatment of sputum-positive pulmonary tuberculosis in South India. Am Rev Respir Dis 1986;134:27-33.

17. Crowle AJ, Ross EJ. Inhibition by retinoic acid of multiplication of virulent tubercle bacilli in cultured human macrophages. Infect Immune 1989;57:840-4. 